\title{
VIETNAMESE ENGLISH TEACHERS' PERCEPTIONS OF CULTURE IN ELT MATERIALS IN VIETNAMESE UNIVERSITIES
}

\author{
Do Lan Phuong \\ School of Foreign Languages, Hanoi University of Science and Technology, Vietnam \\ phuong.dolan@hust.edu.vn
}

\begin{abstract}
As one of the main purposes of using English today is for international communication and globalisation, English has been mainly used among bilingual speakers of English who come from different ethnic and cultural backgrounds (McKay, 2006; Sharifian, 2014). In such multinational and multicultural contexts, today English learners have to deal with not only linguistic barrier, but also cultural barrier. Therefore, it is crucially important that they are provided with multicultural knowledge and cross-cultural awareness. However, so far, there has been little research into the perceptions of English teachers towards culture used in ELT materials in EFL contexts. Therefore, the research aims to identify how seven Vietnamese teachers of English in two universities in Hanoi, Vietnam perceived culture and the role of culture in language teaching. This paper also seeks to explore how their perceptions influenced the way they taught culture in their English class and the way they adapted and developed ELT materials for their students with the hope that it will provide useful and practical suggestions for developing appropriate ELT materials for EFL teaching contexts. The research is based on a qualitative research which applies mostly in-depth, semi-structured interviews and document analysis. The data of this research reveals that most participants recognized the close and interrelated relationship between language and culture and the crucial role of culture in language teaching. They also identified the important role of English as an international language and cultural differences in ELT materials. Realizing a cultural gap in most of the materials they taught, they tried to adapt the materials based on their students' needs.
\end{abstract}

Keywords: ELT materials; culture and pedagogy; teacher perception

\begin{abstract}
Abstrak: Karena salah satu tujuan utama penggunaan bahasa Inggris saat ini adalah untuk komunikasi internasional dan globalisasi, bahasa Inggris telah digunakan terutama di antara penutur dwibahasa bahasa Inggris yang berasal dari latar belakang etnis dan budaya yang berbeda (McKay, 2006; Sharifian, 2014). Dalam konteks multinasional dan multikultural seperti itu, pelajar bahasa Inggris saat ini harus menghadapi tidak hanya hambatan linguistik, tetapi juga hambatan budaya. Oleh karena itu, sangat penting bahwa mereka dibekali dengan pengetahuan multikultural dan kesadaran lintas budaya. Namun, sejauh ini, hanya ada sedikit penelitian tentang persepsi guru bahasa Inggris terhadap budaya yang digunakan dalam materi ELT dalam konteks EFL. Oleh karena itu, penelitian ini bertujuan untuk mengidentifikasi bagaimana tujuh guru bahasa Inggris Vietnam di dua universitas di Hanoi, Vietnam memahami budaya dan peran budaya dalam pengajaran bahasa. Makalah ini juga berusaha untuk mengeksplorasi bagaimana persepsi mereka mempengaruhi cara mereka mengajar budaya di kelas bahasa Inggris mereka dan cara mereka menyesuaikan dan mengembangkan materi ELT untuk siswa mereka dengan harapan dapat memberikan saran yang berguna dan praktis untuk mengembangkan materi ELT yang sesuai untuk pengajaran EFL. konteks. Penelitian ini didasarkan pada penelitian kualitatif yang menerapkan sebagian besar wawancara mendalam, semi-terstruktur, dan analisis dokumen. Data penelitian ini mengungkapkan bahwa sebagian besar peserta mengenali hubungan yang erat dan saling terkait antara bahasa dan budaya dan peran penting budaya dalam pengajaran bahasa. Mereka juga mengidentifikasi peran penting bahasa Inggris sebagai bahasa internasional dan perbedaan budaya dalam materi ELT. Menyadari adanya kesenjangan budaya di sebagian besar materi yang mereka ajarkan, mereka mencoba menyesuaikan materi berdasarkan kebutuhan siswanya.
\end{abstract}

Kata kunci: materi ELT; budaya dan pedagogi; persepsi guru 


\section{INTRODUCTION}

Culture is widely and generally viewed as 'the whole complex of distinctive spiritual, material, intellectual, and emotional features that characterize a society or social group. It includes not only the arts and letters, but also modes of life, the fundamental rights of the human beings, value systems, traditions and beliefs' (Mayor, 2006, p. 7). Indeed, it has been firmly established that language and culture are intimately interrelated, in which language expresses, embodies and symbolizes cultural reality and functions through representational system to produce and exchange meaning and culture (Hall, 1997; Kramsch, 1998). As such, the teaching and learning of culture is crucially important in the teaching and learning of language, especially when language is used for communication among people who are not from the same cultural background. As today English is an international language, it is usually used among bilingual users of English in intercultural or multicultural contexts. Therefore, in order to maintain successful communication, it is important to promote cross-cultural awareness and understanding among bilingual users of English.

This research was conducted in the Vietnamese tertiary educational system, so the status of English in the Vietnamese educational policy and some problems and issues existing in the English language teaching (ELT) program in Vietnamese universities and colleges will be discussed. Since the implementation of the National Reform Policy "Doi Moi" in 1986, Vietnam has successfully resumed and promoted its economic and political relations with many Western countries, such as the European Union, the United States, Australia, etc. Therefore, the need for teaching and learning English has been significantly increased in Vietnam and thus, the status of English has remarkably risen as well. English has become a must for success in both working and studying, English proficiency has also been required in business, higher education, postgraduate education and job recruitment in Vietnam (Nunan, 2003). To promote the study of English further and to better the quality of English teaching and learning in Vietnam to meet the increasing trends of globalization and internationalization, the Vietnamese Prime Minister issued Decision No 1400/QD-TTg on approving the 10-year National plan for 'Teaching and Learning Foreign Languages in the National Formal Educational System in the Period of 2008$2020^{\prime}$ on September 30 ${ }^{\text {th }}, 2008$ (Hoang, 2018).

Despite the rising status and given priorities of English language teaching (ELT) in Vietnam, there still exist a few problems and issues related to ELT curriculum, materials and methods in Vietnamese universities and colleges. The ELT curricula present one of the most challenging issues in Vietnamese higher education. At tertiary level, the Government issued the general framework curriculum for all institutions, but the question of what to teach is left to each particular institution to decide. As a result, this created diversity on the one hand, but chaos on the other (Hoang, 2018). Although the Government has 'subscribed to the principles of CLT (Communicative Language Teaching) and TBLT (Task-based Language Teaching) as central pillar of government rhetoric' (Nunan, 2003, p.604); in reality, practical reasons such as large classes and the shortage of teaching materials and facilities prevent teachers from adopting these methods.

The two universities in which this research was conducted both belong to the Vietnamese public tertiary educational system; therefore, they both use the same ELT General Framework Curriculum issued by the Ministry of Education and Training (2008). 
They are both situated in Hanoi, Vietnam: one majors in foreign languages, the other majors in science and technology. The reason why I decided to choose these two universities was because I wanted to explore varied perspectives of teachers who were from different settings. Although these universities both experienced the same problems discussed above, they had their own way of teaching and developing materials for their students. As such, I determined to conduct a research to identify how Vietnamese English teachers from two different universities perceived culture in relation to ELT practices and materials in their institutions with the aim to improve the quality of ELT materials for Vietnamese tertiary education in general, and for the two institutions in particular.

Like many other Vietnamese English teachers who are working and studying for the improvement of ELT in Vietnam, I decided to do a research on ELT materials currently used in two Vietnamese tertiary institutions with the hope that it would partly contribute to the development of ELT profession not only in Vietnam, but also in other EFL contexts. Although this research was carried out on a small scale, its findings and suggestions are hoped to help both English teachers and materials writers to adopt more diversified perspectives towards the development of ELT materials for EFL contexts. It also aims to help ELT practitioners make good use of research findings and new understanding of cultural elements to improve language teaching materials and methods. Furthermore, by comparing and contrasting the results of this research with those in the literature, this research also provides a valuable chance to examine how the results of previous studies made by some scholars match the reality of the Vietnamese higher education system.

The theoretical framework of this research includes different studies on culture and its role in language teaching with a focus on cultural content in ELT materials in Vietnamese tertiary institutions. First, it begins with how the term 'culture' in relation to language teaching is defined in existing literature. Second, the relationship between language, culture and identity is identified. Third, the role of culture in ELT is further explored. Next, implications for integrating cultural content into EFL teaching materials are discussed. Finally, a brief overview of the current situation of ELT materials used in Vietnamese tertiary institutions is made.

Culture is traditionally accepted as 'the best that has been thought and said in a society'(Hall, 1997, p. 2). It is the sum of the great ideas represented in the classic works of literature, painting, music and philosophy, which is known as the 'high culture' of an age. Besides, culture also refers to the widely distributed forms of popular music, publishing, art, design and literature, or the activities of leisure time and entertainment, which make up the everyday life of the majority of ordinary people, which is known as the 'mass culture' or the 'popular culture' of an age. However, from a more anthropological perspective, culture is known as the 'way of life' of a people, community, nation or social group. Alternatively, with a more sociological emphasis, it can be used to describe the 'shared values' of a group or of society. Thus, culture is defined by Hall as 'shared meanings or shared conceptual maps' because members of the same culture must share sets of concepts, images and ideas which enable them to think and feel about the world, and thus to interpret the world in roughly similar ways (1997, p. 18).

Furthermore, Atkinson (1999) has recently examined the notion of culture in TESOL to propose a revised view of culture intended to serve TESOL practitioners in the $21^{\text {st }}$ century. He classifies the notion of culture into two possibly extreme perspectives: a 
received view of culture(s) and postmodernist or critical views of culture. By reexamining the concept of culture in TESOL, he suggests that a received view of culture should be replaced by critical and nonstandard views of culture, particularly in the field of TESOL. In addition, as indicated by Atkinson (1999), culture in general is still an understudied notion in TESOL although critical perspectives on culture have started to infiltrate the field.

Fang (2011, pp. 27-31) has reviewed different paradigms of culture including 'static' and 'dynamic paradigms'. On the one hand, 'static paradigm' assumes that 1) the complex phenomenon of culture is captured through simplification; 2) nationality or nation state is adopted as the basic unit of analysis; 3) cultural differences, cultural clashes, and cultural collisions are seen essentially as a problem; 4) cultures can be analyzed in bipolar cultural dimensions along which each national culture is given a fixed indexing; and 5) culture is conceptualized as stable over time. On the other hand, the 'dynamic paradigm' of culture centres around intercultural interaction, and it focuses on 'negotiated culture', and 'multiple cultural identity' (Fang, 2011, p. 29). In the dynamic paradigm, cultural differences are seen essentially not as a problem, but as an opportunity for learning and knowledge transfer, in which cultures are 'negotiated, compromised, embraced, and transferred' (Fang, 2011, p. 30).

Over the past few decades, there have been firmly established arguments that language and culture have intimate relationship and this close relationship has contributed to identity formation. Many authors contend that language and culture are intimately interrelated and thus, this intimate relationship plays pivotal role in identity formation (Kramsch, 1998; Phan, 2008). Kramsch (1998) claims that there is a natural connection between the language spoken by members of a social group and that group's identity. By their accent, their vocabulary, their discourse patterns, speakers identify themselves and are identified as members of this or that speech and discourse community. From this membership, they draw personal strength and pride, as well as a sense of social importance and historical continuity from using the same language as the group they belong to. Therefore, it can be said that culture and cultural identity of a social group are established through language and its users.

Similarly, Phan (2008) concludes that since language and culture are intimately interrelated, language acts as 'social practices' and culture is about 'share meanings', one's sense of identity is constructed within the relationship between language and culture. She argues that "we construct identity through language, as language is used about us, by us and for us. Each of us has embedded within us cultural values, and through language we communicate our culture. Language acts as a means through which identity is communicated, extended, confirmed, constructed, negotiated and reconstituted" (Phan, 2008 , p. 25). As identity is constructed through language, it is important to explore how Vietnamese English teachers construct their identity through their teaching and using of English in this research.

As discussed above, language and culture are closely interlinked and interrelatedly developed; therefore, many authors contend that teaching language should automatically entail teaching culture. In his examination of the notion of culture in TESOL, Atkinson (1999) argues that 'knowledge of language cannot be developed without at the same time developing knowledge of the sociocultural contexts in which that language occurs and for action in which it exists' (p.647). However, since the 1990s, the link between language 
and culture has become more complex due to the global mobility of capital, goods, and people, and to the growing multilingualism of human communication, both in face-toface and in online environments. Therefore, English is not, in fact, a culture-free language, which people can just appropriate for themselves and uses as a tool to get things done. It bears traces of the cultural contexts in which it has been used and contributes to shaping the identity of speakers of English (Kramsch \& Zhu Hua, 2016). Hence, it can be said that language cannot be taught without culture as they are closely interlinked and interrelatedly developed. Nevertheless, as English has now become an international language, it is rather complicated to identify whose culture English belongs to, the culture of its users or the culture of native English-speaking countries?

While many authors argue for the inclusion of culture in language teaching on the basis that one could not acquire the language without an understanding of the culture or cultures with which it is associated, it is still controversial to determine which cultural content should be included in the teaching of an international language, such as English.

Cortazzi and Jin (1999) suggest three types of cultures that can be used in English language textbooks and materials:

1. Source culture: the learner's own culture,

2. Target culture: the culture of a country where English is spoken as a first language,

3. International target culture: a great variety of cultures in English- and nonEnglish-speaking countries around the world.

As one of the main purposes of using English today is for successful communication between users from various cultural backgrounds, Sharifian (2014) claims that it is important to develop not only linguistic and communicative skills of English users, but also their intercultural communication (ICC) skills in a systematic way. In order to do so, learners need to acquire knowledge about another culture and then, they need to reflect on how their own culture contrasts with it. In addition, McKay (2003) recommends the use of international target culture in the teaching of English as it provides an ideal context in which bilingual users interact with other speakers of English in crosscultural encounters, and thus encourages learners to reflect on their own culture in relation to others. Another issue regarding teaching English is that students need to be encouraged not to adopt a 'received view of culture', which sees culture 'as geographically (and quite often nationally) distinct entities, as relatively unchanging and homogeneous, and as allencompassing system of rules or norms that substantially determine personal behavior' (Atkinson, 1999, p. 627), but rather to recognize the diversity that exists within all cultures, particularly in the modern era of travel and migration when cultures are in constant contact. However, McKay (2006, pp. 120-121) contends that 'cultural knowledge often provides the basis for the content and topics that are used in language materials and classroom discussions. Which culture to use in instructional materials needs to be carefully considered in reference to the teaching of an international language.'

On the other hand, Nault (2006) points out several shortcomings of an emphasis on American or British culture. First, it wrongly implies that English-speaking countries' culture is uniform or homogenous and that EFL/ESL learners will never need to communicate with native speakers beyond the geographical confines of Great Britain or the US or will only encounter British or American native speakers in English speaking contexts. Second, the ELT profession's fixation with Anglo-American culture also does 
a great disservice to millions of English speakers in non-Western nations. Therefore, Nault (2006) argues that as English today is truly a global language, we must acknowledge its 'dynamic multicultural backdrop' and recognize the existence of other cultures beyond a monolithic Great Britain or US (p.316). However, he suggests that all references to Anglo-American culture should not be removed from the ELT curriculum because if these highly influential cultures are ignored by EFL educators, learners' understanding of the English language will not be complete.

As suggested by the above authors, in order to find an appropriate approach to ELT materials development, an assessment of whose culture to use in ELT teaching materials needs to be made in the context of specific classrooms and the dynamics that exist among the teacher, students and materials. Even though each type of culture has its own advantages and disadvantages, it is important for language teachers and material writers to consider how intercultural communication skills can be developed in EFL teaching materials.

Since the implementation of the National Reform Policy 'Doi Moi' in 1986, Vietnam has promoted its international cooperation and foreign trade with many countries, e.g. Japan, Korea, Taiwan, Singapore, Hong Kong, Australia, Malaysia, and the European Union. As English is regarded as the major language for communication, scientific and technological development and international commerce, it has been promoted as a major foreign language in the Vietnam's national education policy. The central status of English in foreign language education policy has been confirmed in the Decision No 1400/QD-TTg on approving the 10-year National plan for 'Teaching and Learning Foreign Languages in the National Formal Educational System in the Period of 2008-2020' issued by the Prime Minister on September 30 ${ }^{\text {th }}$, 2008 (Hoang, 2018). As English has become a must for success in both working and studying, English proficiency has also been required in higher education, postgraduate education and job recruitment in Vietnam (Nunan, 2003). In fact, it can be said that the importance of English as a global language has had significant impact on both educational policies and practices in Vietnam.

However, despite the tremendous impact, ELT practices in Vietnamese tertiary institutions still face several issues regarding teaching materials, teaching methodology, teaching facilities, curriculum, etc. As indicated by Denham (1992), like other Expanding Circle countries (Kachru, 1990), Vietnam is also norm-dependent, i.e. the use of English in Vietnam also depends on the native-speaker norm/standard, particularly Britain and America. As a result, Denham (1992) states that Vietnamese teachers of English attach great status to materials and methods developed by the Inner Circle applied linguists even though these may not be appropriate for the Vietnamese context. Truong and Phan (2009) raise the issue of the socio-cultural irrelevancy of global textbooks published by AngloAmerican publishing companies to an EFL teaching context, such as Vietnam. They claim that most ELT materials available in Vietnam are published in native English-speaking countries, especially Britain and the United States. Although these textbooks claim to be 'international' in content, the characters in the lessons are predominantly represented by native-English speakers. As such, the cultural content of these textbooks is mostly AngloAmerican, which has resulted in the fact that many learners and teachers in Vietnam may find them irrelevant, confusing and difficult to understand (Truong \& Phan, 2009). 
In addition, Phan (2017) considers the lack of teaching materials and facilities as one of the major factors for the low quality of English language training programs in Vietnam. Although many English departments do have resource rooms and receive frequent donations of books from overseas institutions, these resource rooms do not provide satisfactory services to the students and the teaching staff. The reasons given are poor management, maintenance and security fear. Therefore, gaining access to modern language learning and teaching books is a problem for teachers and students, which may partly affect the quality of teaching and learning English in Vietnamese universities. Furthermore, Phan (2017) presents some challenges or constraints that Vietnamese English teachers might encounter in their teaching of English language, e.g. the lack of supportive learning environments, teaching facilities and teaching materials reflecting the diversity of English. Most participants in her study reported that they used textbooks as their main guides to English teaching methodology; however, the current course books are mainly imported from America and Britain limits the teachers' ability to keep themselves up to date with the recent changes within English.

From the above discussion, it can be said that the major problems associated with ELT materials in Vietnam mainly refer to the socio-cultural irrelevancy of EFL global textbooks and the lack of appropriate teaching materials. As a result, this research aims to investigate this issue in order to suggest solutions for these problems.

The main purpose of this research is to identify the perceptions of Vietnamese English teachers of culture in relation to ELT practices, and then to give suggestions for developing ELT materials for EFL context. The research questions for this study are:

1. How do Vietnamese English teachers perceive culture in relation to ELT practices and materials?

2. How do their perceptions influence the way they teach cultural content and develop ELT materials?

3. What are the Vietnamese English teachers' suggestions for developing ELT materials for EFL context?

\section{METHODOLOGY}

As the purposes of this research are to explore Vietnamese English teachers' perceptions of culture in ELT materials in Vietnamese universities and then, provide suggestions for developing teaching materials, this study adopts a qualitative approach. Qualitative research is defined as 'a way of knowing in which a researcher gathers, organizes, and interprets information obtained from humans using his or her eyes and ears as filters'(Lichtman, 2013, p. 5). She also stresses that qualitative research is about humans as it aims to describe and understand human experience, human phenomena, human interaction, or human discourse. Creswell (2018) also contends that qualitative research is a means for 'exploring and understanding the meaning individuals or groups ascribe to a social or human problem' (p.4). Qualitative researchers usually collect data in the participant's setting, analyze data inductively from particular to general themes, and make interpretations of the meaning of the data (Creswell, 2018). This research seeks to explore how Vietnamese English teachers perceived culture in relation to ELT materials currently used in Vietnamese universities. It also aims to understand how their perceptions affected the way they taught and developed teaching materials. Hence, it is appropriate to adopt a 
qualitative approach to this research as it allows the researcher to investigate other people's experiences, opinions and perspectives in their own context or setting.

\section{Data collection methods}

This research employs two research methods to collect data: in-depth, semi-structured, face-to-face interviews and documents analysis.

\section{In-depth, semi-structured, face-to-face interviews}

Qualitative interviewing is defined by Lichtman (2013) as 'a group of methods that permit you to engage in a dialogue or conversation with the participant with a purpose' (p.139). In qualitative interview, the interviewer/researcher tries to set up a situation in which the individual being interviewed will reveal his or her feelings, intentions, meanings, sub contexts, or thoughts on a topic, situation, or idea (Lichtman, 2013). In-depth, semistructured, face-to-face interview allows the interviewer/researcher to listen thoroughly to the participants' answers in order to explore their perspectives on the complex issue of culture in teaching materials. In addition, a face-to-face interview with the participants, which is regarded as 'a communicatively rich mode of exchange' by Gibson \& Brown $(2009$, p. 94), also enables the interviewer/ researcher to capture significant non-verbal cues, e.g. facial expression, gestures, postures, silences and pauses, to understand the meaning generated by the participants more clearly. As such, in-depth, semi-structured, face-to-face interview seems to be the most suitable method for collecting data of this research.

\section{Participants}

The participants of this study comprised seven English teachers (one male and six females), their ages ranged between 25 and 40, and their experience varied from one to 17 years of teaching English in two different universities in Hanoi, Vietnam. Two participants recently finished their Master course in TESOL in two Australian universities, one earned her Master's degree in English Linguistics in one Vietnamese university, and the remaining four participants hold their Bachelor's Degree in different universities in Hanoi, Vietnam. Four participants came from a science and technology major university and three from an English major university. (See Appendix 2 for more demographic features of the participants). The reasons why participants were selected from two different universities were to improve the validity of data by comparing and contrasting data from different sources (Wiersma, 2000) and to understand how English teachers from two different universities perceived culture and developed teaching materials for the General English (GE) program.

In order to seek participants, advertisement letters which provided the general outline of the project and the researcher's contact details were sent to invite participation to the two selected universities. The participants were selected based on 2 main criteria: they have at least a 2 year-experience in teaching English at a university in Hanoi, Vietnam and they have experience in selecting or compiling ELT materials. Subsequently, the participants who met the set criteria were contacted through email, the Explanatory Statement and Consent Form were sent to them to explain the purpose and requirements of the research. The participants were also notified that their participation is voluntary and confidential, and that their names and related information will not be identified by 
being replaced with pseudonyms according to the Code of ethics for research project involving humans. They were also informed that they can withdraw from the study at any time, even after signing the Consent Form. Once they agreed to sign in the Consent Form, the interviews were conducted at a time and location suggested by the participants as it may help them feel more confident and comfortable to share their ideas and opinions more easily (Gillham, 2005). Hereinafter, the female participants are called by pseudonyms: Huong, Nga, Yen, Van, Tuyet, Trang and the male participant Hoang. The length of each individual interview ranged from 30 to 45 minutes and all the interviews were recorded by a digital voice recorder and transcribed to be used as the data of this study. The interviews were mostly conducted in English; however, code-switching between English and Vietnamese was also used to clarify and ensure that their ideas were clearly expressed and understood. After the interviews were transcribed, interview transcripts were sent to participants to review and approve them before analyzing them. As it was a small-scale study conducted in a short period of time (4 months), the amount of data generated from seven interview transcripts was appropriate for the researcher to manage and analyze.

\section{Documents analysis}

As the researcher aims to explore how Vietnamese English teachers perceived culture and how their perceptions influenced the way they developed teaching materials, it is important to analyze the teaching materials that they developed and used for their students. These written materials can provide a reliable and fruitful source to better understand the teachers' perceptions, thoughts, ideas and meanings. Therefore, the participants were asked to bring with them samples of the teaching materials used in their English classes. By analyzing materials used by the participants, the researcher can understand how their perceptions of culture were affected by the materials they use, which could not be comprehended by solely listening to the participants' opinions. Hence, these written materials were convincing and clear evidence to illustrate and elaborate on what the participants said in the interviews.

\section{Data Analysis and Interpretation Methods}

The method used for analyzing and interpreting data is thematic analysis. After conducting the interviews to generate data, the interviews were transcribed, coded, and then categorized to generate themes and meanings. According to Gibson \& Brown (2009), thematic analysis - a very common aspect of qualitative enquiry - refers to 'the process of analyzing data according to commonalities, relationships and differences across a data set', and the word 'thematic' relates to the aim of searching for aggregated themes within data (p. 127).

In the first stage of data analysis, the interviews made with the participants were transcribed, and then coded. There are three sorts of coding in qualitative research: 'descriptive', 'topic' and 'analytic' (Richards, 2005, pp. 87-88). Descriptive coding involves storing information about the cases being studied or information about the attributes of these cases, for example, the person's gender, the school's size, etc. Topic coding, which merely allocates passages to topics, is thought to be 'almost always easy to do and almost always boring'; hence, can be used early in the data analysis process (Richards, 2005, p. 92). On the other hand, analytic coding, which refers to coding that comes from interpretation and reflection on meaning, is considered to be "the hardest and also the most rewarding', and well-handled analytic coding is a prime way of creating 
conceptual categories and gathering the data needed to explore them (Richards, 2005, p. 94). In fact, this research used both, topic coding and analytic coding, because while the topic coding is relevant in the early stage of data analysis, analytic coding is much relevant in the later stage - creating categories and generating themes.

In the final stage of data analysis, themes were generated by categorizing, sorting, sifting and combining the codes identified in the coding stage. In fact, the themes emerged from the data via a process of reading and thinking about the data. Analyzing data is an iterative process, in which the interview transcripts were read and dissected into manageable parts, categorized into codes, and then codes were organized into categories and subcategories, which later became themes and findings of this research. After that, the findings were related to literature review and research questions in order to make interpretations of the analyzed data.

\section{Triangulation}

In order to improve the validity of this research, triangular techniques were adopted by concurrently employing two research methods: semi-structured interviews and documents analysis. Documents can be used to compare, for example, how some people explain an issue and how they document it (Gibson \& Brown, 2009). This may be used to 'cross validate' or triangulate one's data, but it may also simply be a means of exploring the ways in which different contingencies or contexts place different requirements on how particular issues are to be recorded, represented or talked about (Gibson \& Brown, 2009, p. 70). By combining documents with other data sources, researchers can explore their research setting in a comparative way, and help them to look at their setting from more than one perspective (Wiersma, 2000). Hence, employing two research techniques at the same time seems to improve the validity of the data and help the researcher to be confident about the credibility of the findings of this research.

\section{FINDINGS AND DISCUSSION}

Based on the research questions, literature review and data analysis, three major themes were identified from the data, which are: (1) the participants' perceptions of culture in ELT practices and materials, (2) the way of teaching culture in the participants' teaching practices, and (3) the way of adopting and developing ELT materials for their teaching contexts. Each theme is divided into two main parts: findings and discussion. The first part summarizes and analyzes the findings of the research based on what the participants said in the interview, which will be presented in their exact words in English. Even though all participants came from non-native English background, I decided to keep their original words in English as it is a good way to represent their perceptions. Please note that pseudonyms were used to identify participants and to maintain anonymity. The second part discusses the findings in relation to Literature Review section presented above.

\section{The participants' perceptions of culture in ELT practices and materials}

The first research question aims to identify how participants of this study perceive culture in relation to ELT practices and materials. Therefore, the six interview questions were designed to explore how they defined culture in general and in relation to ELT practices with a focus on ELT materials used at their tertiary institutions (see Appendix 1, question 
5 to 10). Regarding the participants' perceptions of culture, three key sub-themes are emerged from the findings:

1. Culture is a set of values shared by a group of people

2. Language is one aspect of culture and culture has great influence on language development

3. The domination of target cultures in ELT materials used in the participants' institutions

\section{a. Culture is a set of values shared by a group of people}

In response to the question concerning the concept of culture in general, most participants shared a common view which conceptualized culture as a set of values shared by a group of people. Culture in general was defined by most of the participants as a broad concept which covers the way of thinking, behavior, lifestyles, traditions, customs, habits, language, arts, beliefs, religions, etc. shared by a group of people living in a nation or in a particular geographic region.

Nga: "Culture is a set of values shared by a group of people."

Hoang: "Culture refers to a common pattern of behavior or thinking in a group of society. That pattern is usually well-established and is very hard to change. And my thinking is that culture in a broad sense refers to what we often do or what we often think."

Huong: "Culture is something that makes people in different countries distinguish, for example, the way we eat, the way we celebrate the ceremony, the way we say hi, say goodbye, anything in life that makes people different and makes them unique belongs to a country or a nation, like whenever we look at Vietnamese people wearing Ao Dai, we can distinguish them from the Westerner if we don't consider other factors, for example, hair, eyes, skin, such kinds of thing."

Based on the perceptions of culture mentioned above, it can be said that most participants shared a similar view with Hall (1997) and Kramsch (1998), who define culture as the shared values, shared meanings and shared conceptual maps of a group of people or of society. In addition, most participants perceived culture not as an abstract and ambiguous concept; but rather it was related to real-life aspects such as food, clothes, lifestyles, festivals, greetings, behavior, thinking, religions, customs, habits, etc. This way of perceiving culture by the participants seemed to make them develop materials which are more familiar and relevant to their students' needs and interests.

However, the participants' common perception of culture can be identified as a 'received view of culture' (Atkinson, 1999, p. 626), which is suggested being replaced by a critical view of culture, which recognizes the diversity existing within all cultures, particularly in the modern era of travel and migration when cultures are in constant contact. Additionally, since English has become an international language, it is really controversial to investigate which culture English today belongs to (McKay, 2002, 2003). In the teaching of English as an international language, it is crucial that teachers of English should adopt a more critical view or a 'dynamic paradigm' towards culture as it helps them see cultural differences not as a problem, but rather as an opportunity for learning and knowledge transfer, in which cultures are 'negotiated, compromised, 
embraced, and transferred' (Fang, 2011, p.30). This view of culture will be more appropriate for learners of English in the era of globalization and internationalization.

\section{b. Language is one aspect of culture and culture has great influence on language development}

Regarding the relationship between language and culture, a large majority of participants acknowledged the close relationship between language and culture in which language was one aspect of culture and culture was reflected in language and had great influence on language. Hoang said: "There is close relationship between language and culture because language takes route from what we often think or what we often do and because language reflects our thoughts, our perceptions, our conceptions. Therefore, I strongly believe that language has close relationship with culture and culture itself is not only reflected in language, but also has strong influence in the language."

Other participants also recognized the influence of the relationship between language and culture on the way language was developed. They agreed that language could not be taught without culture and culture played a major role in language learning and teaching. Tuyet recognized the important role of culture in language learning and gave an example of how culture should be taught to facilitate Vietnamese students in learning English: "When we learn a language, we need to know something about culture in order to know what to say and what not to say. For example, Vietnamese speakers try to turn down or refuse a compliment because in their culture, turning down a compliment shows modesty but it could be confusing to English speakers, so they are taught to say 'Thank you' when they get a compliment."

Furthermore, Nga explored that culture provided the context, the environment for language to be developed: "Culture is the content, the environment, the context that provides the springboard for language to develop, for example, if you learn a language but you don't really put that kind of language in a certain context, then the language you learn is just the structure, just the skeleton of everything."

As we can see from the data above, most of the participants' perceptions on the relationship between language and culture are in resonance with those mentioned in the literature by Hall (1997) and Kramsch (1998) who argue that language and culture are interrelated and interconnected in a sense that language is a crucial means to express, symbolize and represent culture. Kramsch (1998) also states that language is not a culturefree code, distinct from the way people think and behave, but rather, it plays a major role in the perpetuation of culture. Phan (2008) also recognizes the interrelated relationship between language and culture in which language is social and cultural practices that always carries social and cultural messages, and is used as a way to communicate culture and social practices. As such, this view of the relationship between language and culture was clearly identified by most of the participants.

\section{c. The domination of target cultures in ELT materials used in the participants' institutions}

Regarding the questions about how the participants perceived cultural content of ELT materials used in their tertiary institutions, most participants viewed English as belonging to native English-speaking countries and their people; consequently, most of them emphasized the domination of native English-speaking cultures in ELT materials 
currently used in their institutions and the lack of materials which focus on Vietnamese culture.

Huong: "I mean native English-speaking countries' cultures dominate all the materials that I have, maybe because they are native English-speaking countries, so they develop more materials for teaching English, so it is really hard to find such kind of thing to teach English like a text talking about Vietnamese culture."

Yen: "Most of the coursebooks we are using to teach our students now mainly focus on native English-speaking countries' cultures. Very hardly can I find some pieces of text that mention about English speakers, but from other cultures like Japan, Korea or Singapore."

Moreover, some participants also contended that the domination of target cultures in ELT materials caused problems and difficulties for their students in learning English. Trang pointed out some difficulties her students may face and raised a question about the appropriateness of target cultures to her teaching contexts: "The textbooks we are using now mainly base on target language cultures, that may cause difficulties for students in listening. You know, one of the difficulties with listening is unfamiliar topic. So, when I come across the unfamiliar topic, it is an obstacle to students. Because that topic does not exist in their country, so how can they understand what the people are speaking or is that worth listening if they cannot use the language in real-life, or they can use it only when they go abroad or only when they come to the target country?"

The above data raises some interesting issues related to the inclusion of cultural content in ELT textbooks. As suggested by McKay (2002), it is important for learners to reflect their own culture in relation to others as a way of establishing a 'sphere of interculturality' (p.205); hence, learners need to acquire knowledge about another culture, and then reflect on how their own culture contrasts with it. On the other hand, Nault (2006) argues that all references to Anglo-American culture should not be removed from the ELT curriculum because if these highly influential cultures are ignored by EFL educators, learners' understanding of the English language will not be complete. Most participants of this research shared the same view with Nault (2006) as they recognized English as belonging to native English-speaking countries and stressed the domination of native English-speaking cultures in ELT materials currently used in their institutions and the lack of materials which represents their own culture. In fact, their perceptions represent a common ELT practice in Vietnam - frequent use of ready-made commercial textbooks published in a native-English-speaking country despite the shortcomings of these textbooks.

To explain for this situation, Trang - one of the participants said: "I thinks it is a dream, we all want to have our own textbook that fits our students' needs and levels, but it is difficult to make it come true because it costs a lot of money and we have to get the help from famous and qualified linguists. "This participant mentioned one of the concerns of almost all English language teachers in Vietnam - the lack of budget and resources to design teaching materials. Moreover, it is also the problem of prestige and fame of the publishers as ELT materials designed by famous textbook writers from a native-Englishspeaking country often gain more reputation, and hence are better sold than those designed by local textbook publishers. Therefore, course designers and English language centres in Vietnam had better use a textbook that is trusted by their students and colleagues than design their own teaching materials that may risk their time, money and 
efforts. It can be explained for the over-reliance on textbooks designed in native-English speaking countries and for the domination of native-English-speaking cultures in ELT materials used in Vietnam.

\section{The way of teaching culture in the participant's teaching practices}

As mentioned in the previous section, the way of teaching culture in the teachers' English class was much influenced by how they perceived this concept. Therefore, this section discusses how Vietnamese English teachers in the study taught culture in their English class in order to clearly illustrate their perceptions of culture in ELT practices. The two sub-themes are generated from the findings: The participants often took the opportunity to teach culture explicitly and the participants often compared and contrasted cultures in their English class.

\section{a. The participants often took opportunity to teach culture explicitly in their English class}

In response to the question about the way to teach culture in their English class, most of participants said that they would take the opportunity to teach culture explicitly in their English class if they had a chance to do so. Hoang said that: "In some lesson if they explicitly mention the cultural differences, I will take advantage of that lesson as a way to teach culture in English classroom. For example, in a lesson in Headway Intermediate course book, they have a lesson in which there is a comparison between America and Britain, so I can take advantage of that lesson to teach about the differences between British-English and American-English."

Nga thought that because culture was something that was underlying, hidden and embedded in the language content, she tried to teach culture explicitly in order to make her students explicitly aware of the issue: "When it comes to a certain teaching point that I find it suitable or relevant to what I am teaching, I try to do my best to introduce everything that I know about it, especially the thing that is underlying, that is hidden and embedded in the language content, that sometimes Western people just assume that we know and just assume that people are expected to behave like that, but if students are not taught about that, sometimes they don't know. So, I try to teach it explicitly."

Even though culture was not a compulsory part in English lesson, data reveals that most of the participants tried to integrate the cultural content into their English lesson as they thought the cultural background knowledge would help their students to understand and acquire language better.

\section{b. The participants often compared and contrasted cultures in their English class}

In fact, data has shown that the most common way of teaching culture among the participants was to compare and contrast target cultures with Vietnamese culture. Most of them believed that by comparing and contrasting cultures, students may develop cultural understanding, remember the lesson better and find the lesson more interesting. Huong said: "Whenever I teach my students anything, I try to point out the differences in culture between the countries in the text and in the material and the culture of Vietnam. For example, when I taught my students a reading text relating to Scotland and they saw a picture with a man wearing a skirt, I explained to them and compared with the case in 
Vietnam when a man wearing Ao Dai. So, I think it is easier for them to understand and remember."

Yen also pointed out the necessity to compare and contrast cultures when teaching non-verbal communication in her class of presentation skill: "If I have a chance, I often include, for example, we study about non-verbal communication, so for presenter, when standing in front of his or her audience to speak, some cultures accept the case that the speaker or the presenter put one hand in his pocket and move the other hand, or put both hands in the pocket, but some consider as impolite. So, I think it is necessary to point out to students the differences among different cultures."

In addition, Trang stressed the importance on the students' interests: "I think students are more motivated when they know more about culture, so I try to bring cultural points from different cultures, and make comparison, try to find similarities and differences and explain the similarities and differences between cultures to make the lesson more interesting."

On the other hand, one participant emphasized that she just introduced cultural knowledge very quickly and gave her students some examples to show the reflections of Vietnamese culture into the use of English in order to help her students understand and use language properly. Tuyet said: "I don't spend too much time comparing culture because as I say, the focus is not on finding out the differences in cultures. So, I just give them some examples to show the reflections of Vietnamese culture into the use of English, which would cause some confusion. For example, Vietnamese people often greet each other by saying 'Where are you going?' or 'What are you doing?', I show them that when we speak in English, these questions are considered personal questions, so we shouldn't ask like that, instead we should say 'Hello' or 'How are you?'”.

Regarding the way of teaching culture in their teaching practices, most of the participants explained that they tried to teach culture explicitly and tried to compare and contrast target cultures with Vietnamese culture whenever they had an opportunity. As discussed in the previous section, the way that the participants perceived culture significantly affected the way they taught culture in their English class. As participants thought that culture was something underlying, embedded, and hidden in the language content, it is essential that they should explicitly explain the cultural knowledge so that their students may know how to use language properly, for example, how to make polite request, how to greet, how to apologize, how to express gratitude, etc. However, as mentioned by one participant, culture could sometimes be taught implicitly, for example, when teachers correct students' word choices and grammar. Therefore, it can be said that the teaching of culture should not be separated from the teaching of language since culture is usually woven into language learning contexts whether the focus is explicit or not.

\section{The ways of adapting and developing ELT materials in the participants' institutions}

In this section, the way Vietnamese English teachers adapted and developed materials for their teaching contexts will be discussed. The findings in this part were withdrawn from the interview transcripts and from the analysis of one ELT course book used at one tertiary institution in Hanoi, Vietnam. From those data, two main ways for adapting and developing ELT materials can be identified: course materials are often compiled from 
well-known EFL global textbooks and teachers tried to adapt materials to meet their students' needs, wants and interests.

\section{a. Course materials are often compiled from well-known EFL global textbooks}

Based on the findings from the interview transcripts, all participants admitted the fact that most of the course materials used at their institutions was compiled from different EFL global textbooks designed and published by well-known Anglo-American publishing companies such as Oxford University Press, Cambridge University Press, or McMillan. The reasons for them to depend on such materials were because of their reputation and availability. Hoang said that: "The ELT materials which we are using at the university are quite diverse and they are usually chosen by the team leaders in my faculty. And usually they select materials from well-known publishers like Oxford University Press, McMillan or Pearson, etc."

Trang said: "We work with different listening course books, like Contemporary topics 1 \& 2, Developing Tactics for Listening, Listen-in, Advanced Listening \& Notetaking, Listen Carefully, a lot. We base on authentic textbooks designed by famous publishers and experienced language experts."

Besides, Huong and Trang also stressed the lack of materials exclusively designed for Vietnamese students as one of the main reasons for the dependence on ELT materials designed and published in native English-speaking countries:

"I think maybe because we have no one specialized in designing such materials for Vietnamese students, but I think if we can write a book that uses our ideas that must be wonderful..." (Huong)

"I think it is a dream, we all want to have our own textbook that fits our students" interest or level, but it is difficult to make it come true because you know, it costs a lot of money and we have to get the help from famous and qualified linguists. So, we just collect some textbooks available and we make some adaptations." (Trang)

Based on what the participants said above, we can see that the course materials used at their institutions were mainly compiled from EFL global textbooks because of their reputation, availability and the lack of materials exclusively designed for their students.

\section{Document analysis: one English course book used at one tertiary institution}

In order to explore how the participants' perceptions of culture were affected by the materials used for teaching English in their teaching context, one of the course books used for teaching speaking skill at one participant's tertiary institution in Hanoi, Vietnam was analyzed. This course book was compiled by a group of English teachers in this institution. In fact, it was based mainly on one ELT commercial textbook titled “Discussions A-Z' by Cambridge University Press (2010). Even though the textbook was devised and adapted to meet students' needs and levels, the main topics and contents of this textbook were kept unchanged. This course book was analyzed in terms of its cultural content to explore how the teachers' perceptions of culture were affected by the materials they use.

Generally, this course book employs several topics that seemingly relevant to students such as love, money, travel, entertainment, home, family, jobs, holiday, predictions, superstitions. Such topics are thought to be motivating and interesting to 
students as they provide them with chances to speak about their own lives and perspectives. However, besides these topics, a great number of topics and sub-topics used in this course book may cause difficulties and confusion for Vietnamese students and even teachers who may not be familiar with Western culture, for example, 'kissing', 'hugging', 'making love' (Unit 3: Love and Money); 'polyandry', 'polygamy', 'monogamy', 'kibbutzim' (Unit 4: Home and Family); 'crime', 'bribery', 'murder', 'corruption', 'morality' (Unit 7: Values), 'presidential election' (Unit 9: Predictions). In fact, it can be said that these topics come mainly from the urbanized, Western culture which is still largely alien to the majority of Vietnamese students who come from rural areas, or may be familiar but embarrassing and difficult for them to discuss in public.

In addition, it can be easily seen that most of characters illustrated in pictures and photos throughout this course book are middle-class, Anglo-Saxon, native-English speakers. These characters also represent a stereotypical Western lifestyle, for example, driving cars to work in the morning, having bread, bacon and coffee for breakfast, gardening or dining out at weekends, going overseas in summer vacation, etc. Furthermore, most of proper names of people and places are also typical Anglo-American such as 'Mr. Davis', 'Mrs. Kelly', 'Mr. Douglas', 'Mr. Smith', or 'Hollywood', 'Casa Blanca', 'Cornwall', 'Buckingham Palace', 'Trafalgar Square'. In addition, many culture-embedded words are frequently used throughout the course book, e.g. 'priest', 'monarch', 'shepherd', 'car park attendant', 'usher', 'baby-sitter', 'assembly line worker' (Unit 11: Jobs and Training), 'hiking', 'pony-trekking', 'bungee jumping', 'white-water rafting', 'pot-holing', 'hot-air ballooning' (Unit 12: Travelling and Entertainment).

Although the teachers tried to integrate Vietnamese culture into the course book by including some activities such as 'giving advice to foreigners who want to visit Vietnam', or 'planning a holiday to some Vietnam's famous tourist destinations like Sa Pa, Hoi An, Ha Noi, or Ho Chi Minh city' (Unit 12: Travelling and Entertainment), this course book emphasized much native English-speaking cultures, particularly Anglo-American culture; as a result, most of the participants identified the domination of native-Englishspeaking cultures in the materials they used and the problems caused by the cultural inappropriateness of these materials to their teaching contexts.

\section{b. Teachers tried to adapt materials to meet their students' needs, wants and interests}

As discussed in the literature review, in order to cope with the socio-cultural irrelevancy of the EFL global textbooks to the local contexts, the local educators have to appropriate their teaching materials to meet their students' needs (Truong Bach Le \& Phan Le Ha, 2009). As can be seen in the data of the interview transcripts, the participants also tried to adapt the teaching materials to be more appropriate to their students by different techniques such as changing the format of the textbook, integrating the four language skills, including their own designed activities, or replacing irrelevant and uninteresting topics and activities with more appropriate ones.

For example, Huong said: "Last year, when I taught reading with one of the textbooks, all of the teachers said that it is a boring book and even my students did not show much interest in that book, but I tried to make it more interesting by changing the 
format of the book, integrating reading with listening, speaking and writing for the same topic, and including some games, so it is more interesting."

Yen gave an example of the occasion in which she included her own activities: "I often choose some special occasions to include my own activities, for example, when Christmas is coming, I find songs about Christmas and then do something like gap-filling, and I play the track for students to listen and fill in."

Van elaborated on how she coped with some problems arising in using the course materials: "Actually for the first time teaching a kind of material, of course, we agree that sometimes some of the activities are not very suitable for students, and if we can foresee the situation, we can have some changes, but if we cannot have anything different, we have to draw experience and then we replace them with more relevant activities in the later class."

Furthermore, Tuyet pointed out the way she adapted her materials based on her students' interests: "Most of the time I use available sources from other resource books, but I have some kind of adjustment or modification when I bring it to my class...I will base on some kind of small talk with students during the interval or the break-time, with their observation based on my listening to their conversations, reading or listening to other conversations of young people, or students in Vietnam, I try to find out what are their interests, and I adjust based on those things."

As discussed earlier in this section, the participants of this study had to depend on EFL global textbooks designed and published by Anglo-American publishing companies because of their reputation, availability, and the lack of materials exclusively designed for their teaching contexts. Although they were aware of the cultural inappropriateness of these materials, practical reasons such as limitations in time, funds, professional textbooks writers, and printing facilities often led them to depend on the pre-packaged, ready-to-use materials designed and published by Anglo-American publishers. Their perception is consistent with the voices of Vietnamese English teachers in the study by Phan (2017) about the challenges and constraints in teaching today English in Vietnam. Phan (2017) claims that although most teachers in the study realized the importance of teaching different varieties of English and cultures to prepare learners for intercultural communication, teachers find it hard to change their current teaching practices due to the lack of teaching materials, teaching facilities and supportive environment.

Therefore, to overcome the difficulties caused by the lack of appropriate teaching materials for their teaching context, the participants tried to adapt and adopt the readyto-use materials by various techniques such as changing the format of the textbook, integrating the four language skills, including their own designed activities, or replacing irrelevant and uninteresting topics with more appropriate ones. Furthermore, most participants agreed that they should adapt materials based on their students' needs, wants, interests, and purposes of learning English. For example, one participant who taught at a technology-majored institution suggested that teachers should encourage their students to tell their interests and to give their own suggestions about the selection of the topics and the main content of the coursebook. Another participant believed that teachers should make some changes to the materials based on their experience, their observation of their students in class, during the interval or break-time, their conversations with them, or listening to their conversations. In short, the participants of this study suggested a new way to adapt materials for an EFL context - collaboration between teachers and students, 
in which students can suggest what they want to learn in the classroom and teachers can adapt materials based on their students' needs and interests.

\section{CONCLUSION AND RECOMMENDATIONS}

The research presented the perceptions of Vietnamese English teachers of culture and how those perceptions affected the way they taught cultural content and developed materials for their teaching context. As presented in the Findings and Discussion section, all participants of this research perceived culture as 'a set of values shared by a group of people' and recognized the important role of culture in language teaching; hence, they tried to teach culture explicitly in their English class and compare and contrast cultures to develop multicultural knowledge and cross-cultural awareness for their students. However, most participants admitted using materials from well-known EFL global textbooks as their main teaching materials even though they recognized the domination of native English-speaking cultures in those textbooks. Their perceptions were also reflected through a course book used to teach speaking skill at one tertiary institution where some participants of this study were working for.

However, this research faced the issue of bias and subjectivity as the researcher shared many things in common with the participants. Even though the researcher tried to avoid this issue by adopting two research methods (semi-structured interview and document analysis), bias and subjectivity still possibly occurred when she interpreted data. As such, it may partly affect the validity of this research. In addition, although this research aimed to identify the perceptions of Vietnamese English teachers towards culture in ELT materials; indeed, due to the length and scope of this study, it had a small-sized sample of only seven participants who taught English in two different universities in Hanoi, Vietnam. As a result, these participants cannot represent the perceptions of all Vietnamese English teachers, and thus the findings of this research cannot be used to generalize about the whole ELT materials in the Vietnamese tertiary educational system.

Despite the above limitations, this research partly contributes to the studies on developing teaching materials for the EFL context. Even though there have been several studies about ELT teaching materials, little research has been done about ELT materials in relation to culture. Therefore, by focusing on culture in ELT materials in the Vietnamese tertiary education context, this research aimed to identify Vietnamese English teachers' perceptions of culture teaching in relation to EFL textbooks. In addition, based on these perceptions, practical and useful suggestions for developing appropriate ELT materials for Vietnamese teaching context are also provided. Furthermore, although this research was conducted in the specific context of Vietnam, its findings are expected to contribute to other EFL settings.

Based on the above limitations of this research, directions for further studies can be suggested. With the main purpose of giving suggestions for developing teaching materials for the EFL context, this research studied the perceptions of Vietnamese English teachers towards culture teaching in relation to ELT materials. However, as students are the main target for which materials are selected, adapted and developed (Tomlinson, 2013), it would be a more comprehensive and reliable research if the researcher can study students' perceptions, needs and wants of ELT materials. As such, students' perceptions and needs of culture learning in relation to ELT materials can be another focus of further study. In addition, in order that the findings of this research can be generalized, further study should 
enlarge the scale of the sample and select participants from different contexts and settings. Also, to improve the validity and reliability of this research, class observations or qualitative survey can be conducted alongside the two existing research tools of this research (in-depth, semi-structured, face-to-face interview and document analysis). Furthermore, in-depth interviews with materials or textbooks writers can also be conducted to provide more useful and valuable suggestions for developing teaching materials for EFL contexts.

Although some Vietnamese English teachers recognized the necessity for diversifying culture and English varieties in ELT materials; in reality, it seems that these immediate changes may not happen in the near future in Vietnam due to the real situation of teaching English in Vietnamese tertiary institutions. In order to make these changes, it requires long-time and thorough investment in education at both macro and micro level. At macro level, it requires the governmental investment in improving the quality of ELT textbooks used at Vietnamese tertiary institutions with the assistance and collaboration of qualified global EFL textbook writers. However, this seems to be infeasible and cost ineffective as it is difficult to design materials that can meet the requirements of all Vietnamese tertiary institutions. Hence, it would be more feasible and practical if each individual teacher at micro level could adapt materials to be more appropriate to their students and their English classes.

\section{REFERENCES}

Atkinson, D. (1999). TESOL and Culture. TESOL Quarterly, 33, 625-654.

Cohen, L., Manion, L., \& Morrison, K. (2018). Research Methods in Education (8th ed.). London/ New York: Routledge.

Cortazzi, M., \& Jin, L. (1999). Cultural mirrors: materials and methods in the EFL classroom. In E. Hinkel (Ed.), Culture in Second Language Teaching (pp. 196219). Cambridge: Cambridge University Press.

Creswell, J. W. \& Creswell, J. D. (2018). Research design: qualitative, quantitative and mixed methods approaches (5th ed.). Los Angeles : SAGE Publications Ltd.

Crystal, D. (1997). English as a global language. Cambridge: Cambridge University Press.

Denham, P. A. (1992). English in Vietnam. World Englishes, 11(1), 61-69.

Fang, T. (2011). Yin Yang: A New Perspective on Culture. Management and Organization Review, 8(1), 25-50.

Gibson, W. J., \& Brown, A. (2009). Working with qualitative data. London, UK: SAGE Publications Ltd.

Gillham, B. (2005). Research Interviewing: The range of techniques. London, England: Open University Press.

Hall, S. (1997). Representation: cultural representations and signifying practices. London: Sage.

Hoang, V. V. (2018). The current situation and issues of the teaching of English in Vietnam.

Kachru, B. (1990). World Englishes and Applied Linguistics. World Englishes, 9, 3-20. 
Kramsch, C. (1998). Language and Culture. Oxford: Oxford University Press.

Kramsch, C., \& Zhu Hua. (2016). Language, Culture and Language Teaching. In G. Hall (Ed.), Routledge Handbook of English Language Teaching (pp.38-50). London: Routledge.

Lichtman, M. (2013). Qualitative Research in Education: A User's Guide (3rd edition). London, UK: SAGE Publications Ltd.

Mayor, F. (2006). Culture and the university. Higher Education in Europe, XIV(1), 5-15.

McKay, S. L. (2002). Teaching English as an international language. Oxford: Oxford University Press.

McKay, S. L. (2003). Toward an appropriate EIL pedagogy: re-examing common ELT assumptions. International Journal of Applied Linguistics, 13(1), 1-22.

McKay, S. L. (2006). EIL Curriculum Development. In R. Rubdy \& M. Saraceni (Eds), English in the World: Global Rules, Global Roles (pp.114-129). New York: Continuum International Publishing.

Ministry of Education and Training. (2008). The government: No.1400/QĐ-TTg Decision on the approval of the project entitled "Teaching and Learning Foreign Languages in the National Education System, Period 2008-2020”.

Nault, D. (2006). Going Global: Rethinking Culture Teaching in ELT Contexts. Language, Culture and Curriculum, 19(3), 314 - 328.

Phan, L. H. (2008). The politics of English as an international language and English language teaching. In L. H. Phan (Ed.), Teaching English as an international language: Identity, Resistance and Negotiation (pp. 71-103). Clevedon, UK: Multilingual Matters Ltd.

Phan, N. L. H. (2017). Challenges/constraints in teaching today's English in Vietnam: Teachers' voices, presented at 8th Annual International Conference on TESOL SEAMEO RETRACT, HCMC, Vietnam, 2017. HCMC, Vietnam: SEMEO Publishing.

Phillipson, R. (1992). Linguistic Imperialism. Cambridge: Cambridge University Press.

Sharifian, F. (2009). English as an International Language: Perspectives and Pedagogical Issues. Bristol: Multilingual Matters.

Sharifian, F. (2014). Teaching English as an International Language in multicultural contexts: focus on Australia. In Marlina, R. \& Giri R.A. (Eds) The Pedagogy of English as an International Language: Perspectives from Scholars, Teachers, and Students (pp.35-46). Springer International Publishing.

Tomlinson, B. (Ed.). (2013). Developing materials for language teaching (2nd ed.). London: Continuum Press.

Truong Bach Le, \& Phan Le Ha. (2009). Examining the foreignness of EFL global textbooks: Issues and Proposals from the Vietnamese classroom. In J. Mukundan (Ed.), Readings on ELT Materials III. Malaysia: Pearson Longman.

Wiersma, W. (2000). Research methods in Education: An Introduction. Boston: Allyn \& Bacon. 